\title{
TRINITY DOCTRINE AND CHRISTOLOGY OF SAINT ATHANASIUS, ARCHBISHOP OF ALEXANDRIA, IN HIS LETTER TO EPICTETUS, BISHOP OF CORINTH
}

\author{
Kyriakos S. Stavrianos
}

DOI: 10.17846/CL.2019.12.1.3-12

\begin{abstract}
STAVRIANOS, Kyriakos S. Trinity Doctrine and Christology of Saint Athanasius, Archbishop of Alexandria, in His Letter to Epictetus, Bishop of Corinth. The letter of saint Athanasius of Alexandria to Epictetus of Corinth stands in the place of the most important text of the doctrinal texts of the Christian literature about Christology. It is recognizes to be an important text not only at the Arian controversy, but even after the first Ecumenical Council. Athanasius wrote it to answer series of questions, which come from the views of Appolinarianists, Illusionists and adherents of early Nestorianism. Jesus Christ is the Word of the God, who was incarnated. The Word of God assumed a human nature so that there are two natures truly distinct. He has become a human being to save the mankind. He took the human flesh by Virgin Mary and He was also remaining co-substantial with the God Father. Logos did not suffer during the Passion but only His human nature. There is not a temporal difference between God Father and Word of God.
\end{abstract}

Keywords: Epictetus of Corinth, Arian controversy, Incarnation, Substantial, homoousios, Jesus Christ, Holy Trinity, Human flesh, Word of God

\begin{abstract}
Abstrakt: STAVRIANOS, Kyriakos S. Trojičná dogma a kristológia svätého Atanáza, arcibiskupa Alexandrie, v jeho liste Epiktétovi, biskupovi Korintu. List sv. Atanáza Alexandrijského Epiktétovi Korintskému predstavuje najdôležitejší text z doktrinálnych prác krestanskej literatúry zaoberajúcej sa kristológiou. Dosiahol uznanie svojej dôležitosti nielen vo vztahu $\mathrm{k}$ ariánskemu sporu, ale dokonca aj k obdobiu po Prvom ekumenickom koncile. Atanáz napísal daný list ako odpoved' na sériu otázok, ktoré vzišli zo stanovísk apollinaristov, iluzionistov a stúpencov včasného nestoriánstva. Ježiš Kristus je Slovo večného Boha, ktoré sa vtelilo. Božie Slovo nadobudlo ludskú prirodzenost', a tak sú v ňom obe prirodzenosti od seba odlíšené. Stal sa ludskou bytostou, aby zachránil ludstvo. Prijal ludské telo prostredníctvom Panny Márie a tiež ostával jednej podstaty so svojím Bohom Otcom. Logos netrpel počas umučenia, ale iba jeho ludská prirodzenost'. Neexistuje dočasná rozdielnost̉ medzi Bohom Otcom a Božím Slovom.
\end{abstract}

Klúčové slová: Epiktétos Korintský, ariánsky spor, vtelenie, podstatný, jednej podstaty, Ježiš Kristus, Najsvätejšia Trojica, ludské telo, Božie Slovo

Saint Athanasius wrote this letter, which he sent to the Bishop of Corinth Epictetus, responding to the views expressed by the Hierarch of the Corinth, which were presented to him concerning the nature and origin of Christ. ${ }^{1}$ The importance of the letter to Epictetus is great, as it is recorded by the Ecclesiastical Literature's research; it has the repute of a holy canon in the Christian faith.

The question of who Christ is, it preoccupies the talking leaders of the Christian Church in the first centuries. It will be a main talking point from the 3rd century onwards about the Person of Christ and the fact of the Incarnation of the Word of God. Cf. Tsigos 2014, 143. 
Epiphany of Cyprus in the 2nd Volume of the 3rd book of his writing Against Heresies, and more specifically in the Chapter on the heresy of Demirites, is based on it in order to face this sect and that of Appolinarism. He names Demirites those who did not confess to the perfect Christ's Incarnation. Some of them claimed that the body of Christ was consubstantial to the deity. Others refused to accept that Christ assumed the human soul. Another part of this sect, based on the citation, the Word became flesh (John 1,14), denied that Jesus Christ received the flesh from the Virgin Mary. ${ }^{2}$ Saint Epiphanius considers - writing about this sect - it necessary to quote the letter to St. Athanasius' Epictetus, as bearing great importance for the evidence and support of Orthodox views. ${ }^{3}$

When the controversy of the Cyril of Alexandria against John of Antioch ensued about the existed obscurity of certain points of the Anathematic, the letter of Athanasius to Epictetus was considered along with the Symbol of Nicaea the basis for the agreement of the two sides, which represented the Alexandrian and the Antiochian theological respectively. Acacius of Veria carried the above proposal of reconcilement to Cyril of Alexandria, whereupon the agreement of the two parts was achieved. The teaching of St. Athanasius in Epictetus' letter was included in most of the text of their common confession named Text of Reconciliation (433). ${ }^{4}$ St. Cyril of Alexandria, in his 40th Letter to Acacius responding to their acceptance or not of the deposed proposals, mentions the falsification of the content of St. Athanasius letter to Epictetus by the Nestorians. ${ }^{5}$ The Bishop of Emesus Paul, who was entrusted with the task of reconciliation, asked Saint. Cyril if he accepted the content of the letter, which he presented to him. Cyril replied that if he had the authentic text in his hands, he would have no objection. After comparing the contents of the letters, it was proved that Paul had one of the contents that had been falsified by the Nestorians. Cyril after the verification accepted the authentic letter of Athanasius, to become the basis of the agreement of the two sides and gave it to the Bishop of Emesus to deliver it to John of Antioch. The Fourth Ecumenical Synod included it in its Proceedings as a genuine and excellent expression of faith for Jesus Christ. ${ }^{6}$

Annick Martin in her doctoral thesis on Athanasius of Alexandria and the Church of Egypt repeats stereotypically and unbiased the views of Western theologians and philologists that "although his writings played an important role in the dogmatic controversies of the second half of the 4th century and particularly the letter to Epictetus, as the manuscripts evidenced, Athanasius

\footnotetext{
Epiphanius of Cyprus, 42, 640B.

Epiphanius of Cyprus, 42,644BD.

4 Feidas 2002, 616-618. The concerned dogmatic definition is: "We confess, therefore, our Lord Jesus Christ, the Only Begotten Son of God, perfect God, and perfect Man of a reasonable soul and flesh consisting; begotten before the ages of the Father according to his Divinity, and in the last days, for us and for our salvation, of Mary the Virgin according to his humanity, of the same substance with his Father according to his Divinity, and of the same substance with us according to his humanity; for there, became a union of two natures. Wherefore we confess one Christ, one Son, one Lord. According to this understanding of this unmixed union, we confess the holy Virgin to be Mother of God; because God the Word was incarnate and became Man, and from this conception he united the temple taken from her with himself. For we know the theologians make some things of the Evangelical and Apostolic teaching about the Lord common as pertaining to the one person, and other things they divide as to the two natures, and attribute the worthy ones to God on account of the Divinity of Christ, and the lowly ones on account of his humanity". Cf. John of Antioch, 77,172CD. Cyril of Alexandria, 77, 176D - 177AB.

5 Cyril of Alexandria, 77, 200CD; Bardy 1938, 33-34; Haleux 1992, 452,455.

6 Moutsoulas 1989, 74.
} 
does not belong to the class of great theoretical theologians. He wrote every time, not to clarify internal doubts or to literary needs, but to answer urgent pressing questions from others"?

The writing time of the letter is reported to be either $362^{8}$ or 365 , when Apollinaris's views began to spread more widely in the domain of Christianity ${ }^{9}$, while some of them rank it along with the letters to Adelpius and Maximus in the last texts of Athanasius and after the condemnation of Auxentius of Milan, which Athanasius recalls in the letter as a recent event, dating between 370 and $372^{10}$. It is also preserved in two Latin, two ancient Armenian publications, one of which comes from a Georgian translation and a Syrian translation falsified by the Monophysits. ${ }^{11}$ The Armenian text was found in two manuscripts of the Byzantines in Vienna. ${ }^{12}$ In Migne's Patrology, the letter was issued by B.de Mauntgaucon in the 26th Volume. Scholars are skeptical about the critical editions on the grounds that these two critical publications have included manuscripts that have been altered by the heretics. ${ }^{13}$

\section{Ecclesiastic and politic situation}

The First Ecumenical Council in Nice (325) condemned the heresy of Arius, who taught that the Son of God is the first creature of God. Because of creating others creatures too, Christ was called God ${ }^{14}$. Thus, Arius introduces the concept of time into the relationship of the Three Persons of the Holy Trinity, believing that only God being uncreated, is also wholly immutable. The Son and Word of God incarnated himself by taking the place of the soul into the human nature of Christ. The Council, in the formulation of its Symbol, decided that the Son is consubstantial to the God Father and preserved the notion of the Trinity of God. ${ }^{15}$ Athanasius of Alexandria even pointed out in the 2th Homily against the Arians, that there is no time difference between the Father and the Son in the Holy Trinity. ${ }^{16}$ The letter is written during the third $(351-361)$ and fourth period of the Arian controversies $(361$ - 381). Its characteristic is the prevalence of Emperor Constantine, who is associated with the supporters of Arius bishops Ursakius of Singidus (Belgrade) and Walis of Mourson. Their names are mentioned in the letter by Athanasius. At the same time, we observe the trisection of Arianism into the Homoians, Anomoeans and Homoiousians.

The Homoiousians came immediately after the First Ecumenical Council, and especially after the "in consecration" (in Encaeniis) Council of Antioch in 341 (on the occasion of the consecration of the emperor Constantine the Great, Golden Church), where the second symbol of the Council referred to as "an indistinguishable image of the Son and Father", as did the Makrostichos Ekthesis ("the Long Confession of faith") from the Council in the same city in 344 with the phrase "Father

\footnotetext{
Martin 1996, 10; Robertson 1891, 99; Cross 1945, 5.

Tsiomesidis 1975, 13.

Christou 1987, 512.

10 Robertson 1891, 95; Moutsoulas 1989, 74; Martin 1996, 626; Papadopoulos 2010, 338 ; Gwynn 2012, 102.

11 Tsiomesidis 1975, 13; Christou 1987, 512.

12 One of them comes from the Cod. 629 , ff $66 \mathrm{a}-73 \mathrm{~b}$ of the 19th century. It was a copy of an archetype in the 18 th c. in Isfahan and Cod. 648 , ff102b - 105b of the 14th c. See also Casey 1933, 127. Casey states that his version is different from that of Tajezi, 1899, 324-343.

13 Masai 1979, 66; There is an edition in Greek by Ludwing 1911.

14 See Arampatzis 2014, 110.

15 The Byzantine theologians and the Fathers of the Church used Philosophy and philosophical terms to express the Christian doctrine, but they gave a different meaning to the used terms. In there reasoning, "there is a clear connection between science, philosophy and theology, despite the dominant position held by orthodox faith". Cf. Zozulak 2018, 8-10.

16 Papadopoulos 2010, 297; Arampatzis 2014, 111.
} 
substantial at all with Son". ${ }^{17}$ Their leaders were promoted by Basil of Ankara and George of Laodicea. They began to use the term "homoiousios" instead of "substantial". They held the belief that God the Son was of a similar, but not identical, substance to God the Father. This was because these groups could not understand the difference of substance and hypostasis, fearing that the Orthodox portion would accept a person to God as Savellianism was teaching. On the other hand, the Orthodox believed that the reference of the Homoiousians to three hypostases continued the Marian sect. The Anomoeans, led by the Christian Sophist Aetius and the Eunomius of Cappadocia, accepted that the Son is dissimilar in everything the Father. ${ }^{18}$

The Homoians would come later when the first two portions will try to find a common place to meet their views. They taught that the Son is similar to the Father. The birth of the Son is a peculiar mystery, but it is contained in the Bible. These are the leaders of the Homoians, the above-mentioned Ursakius of Signidon (Belgrade) and Walis of Mourses, as well as Acacius of Caesarea of Palestine. The double interpretation and acceptance of the "similar" was either approached by the Homoiousians or the Anomoeans according to their absolute or relative resemblance to the Son with the Father. Thus, firstly, the words homoousios and homoiousios seem to have no difference, but the second word degenerates to have similar notion to that of Arianism. The Homoiousians wanted to satisfy, regarding the issue of this doctrine both the Homoians and Anomoeans, so they did, on a case-by-case basis, by referring to the term "homoousios" or not. The Councils of Ariminum at West in 358 and Seleucia in the East were convened because of these sects. The leaders of the first Council, while remaining in the symbol of Nicaea, at first were finally forced to accept the positions of the Homoians (the Son the God similar to God the Father according to the Scriptures, whose birth nobody has ever been acquainted with and the same was signed by their delegates of them at the Council of Seleucia. ${ }^{19}$

The Orthodox bishops came back from their exile, after the prevalence of Julian the Apostate and thanks to his policy. The Orthodoxs and the Homoiousians were led to an agreement. It became clear that substance and hypostasis are not the identical meanings. So they used the phrase "one substance, three hypostases". The Homoiousians accepted the complete resemblance of the essence of the Son and the Father. After the Council of 362, which was convened in Alexandria by M. Athanasius, the union of the Orthodox and the Homoiousians was achieved by accepting the term "homoousios".

\section{The content of the letter}

G. Athanasius in the Preface of the letter and after the formal heartfelt greeting to the Bishop of Corinth points out that discussions on issues of faith about Christ not had only been resolved and ended after the decisions of the Ecumenical Council of Nicaea, but also, had so far condemned all the heretic sects who tried to fake the image of God Logos and Christ. Then he wonders why there is continuity on the same subject, which had been solved in Nicaea and all those who had been stirring, defending the Arius's doctrines, had been condemned ${ }^{21}$. He essentially wants to state against those whom he addresses this response to the memorandum sent to him by Epictetus of Corinth. All of these heretical views has proceeded either from supporters of Arius ("the Arians

17 Stefanidis 1970, 192; Anastasiou 1983, 269-270 ; Feidas 2002, 497-498.

18 Stefanidis 1970, 193; Feidas 2002, 499-501.

19 Stefanidis 1970, 194-197; Anastasiou 1983, 275-279; Feidas 2002, 501-507.

20 Stefanidis 1970, 198-199; Anastasiou 1983, 280 ; Feidas 2002, 507-510.

21 Athanasius Archbishop of Alexandria, 26, 1049A-1052A. 
come") or from those who, while claiming that they support the sound faith of the Fathers, with the Arius' teachings and arguments, they distort and destroy the sound faith. ${ }^{22}$

The questions which he poses here are the heretical views, as he has encoded and classified them from the writings of Epictetus. Firstly he uses a rhetorical question, "where did he come out of?" that means, "where do they derive from", he wants to show that he primarily defends faith, which, as he says, stems from the teaching of Jesus Christ and not from somewhere else. We present these heretical views, as recorded by the Alexandrian hierarch in a comprehensive report:

1. The body of Christ, which came from the Virgin Mary, is consubstantial with the divinity of the Word.

2. There has been a change of Logos in human elements (bones, hair, flesh, body)

3. The body of Christ was illusory and not real. ${ }^{23}$

4. The circumcision took place in the divine nature of Christ, which was consubstantial with the Father, and it was incomplete.

5. The divine substance was crucified, not the human nature.

6. The sufferings of the body were not made by Mary, but transformed by the Word itself.

7. We must teach the Four Persons rather than the Trinity of deity.

8. The body received from Mary the Word is from the essence of the Holy Trinity.

9. At the same time the body with the divinity of the Word co-existed.

10. Christ is not the Son of God in substance and nature and his body is from that of Mary

11. He who is crucified is not the Savior and God and Son of the Father.

12. Separation of Christ from the Word of God. They are different from each other. Some of the heretics separated the Word from the Son of God. ${ }^{24}$

St. Athanasius reconstructs the heretical views with the following arguments:

1. The teachings of the heretics that the human body of Christ was co-substantial to Godhead. It opposes to what the Bible says and the decision of the Fathers of Nicaea that the God Son is cosubstantial with the God Father, coming from his essence, and that the body comes from Mary. If, it were what the heretics used to say, were to be true the Logos who is co-substantial to the earthly body and is in agreement with the Father, then, in a logical sequence and consequence,

22 Athanasius Archbishop of Alexandria, 26, 1052B-1052C. There are the following views on which are all these heretics are based: a) Illusionists and Appollinarianists See: Christou 1987, 512., b) teachings related to the Apollinarianism and others not named which distinguished the divine and human nature in Logos, Moutsoulas 1989, 74, et. c) for erroneous beliefs related to Arianism, Apollinarianism and Docetism, Papadopoulos S. 2010, 338, d) one part harshly supported the Apollinarianistic Christology and the other the separation between the Word and the Son of Virgin Mary, which is an early Nestorianism,, two factions who, while confessing the decision of Nicaea, were in opposition to it with dangerously extreme views. It was on the one hand the Apollinarianists, and on the other those who they said that the Word fell on Christ as it was in the Prophets, De Tillemont 1702, 242, one group has views similar to those of the Eustathians' dualism, where Christ is different from the Word of God and the other group has a Apollinarianistic tendency (Roldanus 1977, 228-229). He does not name who they were, but leaves a suspicion that everyone can be called Arians (Lebon 1935, 748).

${ }_{23}$ Docetism is a Gnostic tendency, in which the Word was not incarnated, but as such he was presented to human, he was mere semblance without any true reality. Their dualistic perception of the world did not allow them to accept that God would receive the passive flesh of man. They claimed to have crossed Mary without getting flesh. See Matsoukas 1996, 228-232; Tsigos 2014, 146.

24 Athanasius Archbishop of Alexandria, 26, 1053A-1053C. 
the Father is co-substantial to the human body of Christ. In this way, however, there is agreement with the Arius's views that the Son is a creature and the Father co-substantial with the creatures. ${ }^{25}$

2. If we had the conversion of Word into a body, then it would be unnecessary for Virgin Mary to mediate and the same would happen if the body coexisted with the Word forever. There is a substantial downgrading and denial of the important role of Virgin Mary in the Incarnation of the Word through which the Word of God received by the human flesh. So the necessity for the Annunciation and the gestation of Mary did not exist. Apart these, arguments from texts of the New Testament are presented, in which the whole progress of Christ's birth and development (circumcision, reception by Simeon, twelve years in the Temple) and the separation between the deity and mankind of His nature is shown. He also points out that Archangel Gabriel in the Annunciation, by addressing the Virgin Mary tells her that the Son of God will be born "from you" and not "in you"

3. Athanasius, when he is mentioning to the Passion, says that Christ was "the sufferer and the notsufferer." He was the sufferer with regard to the body and not sufferer with regard to the deity. The passionless Word was brought by the passive body. The salvation of man was through the crucifixion of Christ, and in this way man gained non decay and immortality, i.e. he avoided eternal death. The deity remained, as in all His earthly presence, indivisible to human nature, unalterable and imperishable, reaching Hades, to preach to those who were there. The facts about the Passion and Resurrection of Christ, as well as his brief physical presence on earth before Ascension, prove that this was a body that coexisted with the Word. ${ }^{27}$

4. The belief that Jesus only seemed to be human, and that his human form was an illusion is incorrect. The Incarnation took place by nature not by placement, i.e. it was not a deceptive fact of human imagination. If this were the case then the salvation and resurrection of the people would be illusionary. This is what G. Athanasius says, and Manichaeus also supported. But the salvation of man is real and complete; it concerns both the soul and the body and comes from the Word of God. ${ }^{28}$

5. The way of conception and the birth of Christ are, from that moment, the beginning of a problem that will then arise with the formulation of Nestorian heretic views. M. Athanasius clearly states that the Virgin Mary is a human being, coming from our forefather Adam, like all of us. Her particular role was that she became God's election vessel in order for the Word of God to receive flesh. ${ }^{29}$

6. The renaming of the Holy Trinity to Quartet, because of the addition of the body of Christ, shows the perception that the person was a separate entity. So then Trinity had to accept a new addition and become Tetras. In this way, the creator is equated with creation. Heretics do not understand the specificity and purpose of the human body of Christ. The Incarnation of the Word of God was not done to increase the number of persons in Trinity, but to raise man. The addition

25 Athanasius Archbishop of Alexandria, 26, 1053C-1056B.

26 Athanasius Archbishop of Alexandria, 26, 1056B-1057B.

27 Athanasius Archbishop of Alexandria, 26, 1057C-1061A.

28 Athanasius Archbishop of Alexandria, 26, 1062B.

29 Athanasius Archbishop of Alexandria, 26, 1062B-1064B. 
is made to the body of "communion and union" of the Word with him. Thus, the mortal has the potential to become immortal, the mental spiritual and the earthly to ascend into Heaven. ${ }^{30}$

7. The human body suffered on the Cross, but remained the temple of the Word. While being naturally mortal, going beyond this nature, he rose because he had in him the Word of God, who is above man $^{31}$.

8. The view that the Word came to Mary, as was the case with the Prophets, is considered to be non-existent. The Word was born only "from the Virgin in a Supernatural way." Prophets and saints in a natural way. That is why he refers to the Gospel of John by repeating what he claimed in his Third Speech against the Arians that "the Word of Freedom became flesh" and not that "it was carried and born". The Prophets once accepted the Word to prophesy, they died and were not resurrected, like the Word of God after his three-day burial ${ }^{32}$. Consistent with the Alexandrian Reference "Word Flesh", he uses this figure of speech. In the letter to Epictetus, however, he clarifies that the "Logos became flesh" was equivalent to "the Word of Man". In this way, he wants to declare that the Word was God, and in a certain time he became man, leaving no sign of incomplete humanity, to prevent anybody from blaming him for Appolinarism.

\section{Conclusions}

The letter to Epictetus is a dogmatic letter in which St. Athanasius summarizes the teaching of the Church, as formulated till then, about the nature and the person of Christ, but also what he himself had thoroughly and extensively presented in his previous doctrinal texts. The content of this letter would become the bedrock of the faith that it will be used in later theological controversies about the Virgin Mary and about the two natures of Christ. Athanasius of Alexandria, both through the content of this letter and his overall writings, is established not as an occasional writer of theological issues, but as the specialist doctrinaire of the Incarnation of the Word of God. $\mathrm{He}$ don't present an extensive and concrete treatise on a question, since he concentrates on a series of questions, which come from the views of Appolinarianists, Doketaí ("Illusionists") and those of early Nestorianism. But they end up in everything that M. Athanasius seeks every time through his teaching, that is to say, to emphasize the Incarnation of the Word of God and his and His consubstantiality with God the Father, timelessly, indivisibly and inexpressibly. Apollinaris or his followers are not named in this letter, nor are the heretical views, which were rebuilt, contain the basic Appolinarianistic position on whether the Word took the place of the human soul into Christ. This is not because it is considered as a cover for Apollinaris or a latent apollinarianistic tendency by St. Athanasius, but because it is more interesting here for the Alexandrian hierarch to show that the salvation of man is connected with the Incarnation of the Word of God.

30 Athanasius Archbishop of Alexandria, 26, 1064B-1065B.

31 Athanasius Archbishop of Alexandria, 26, 1065B-1068A.

32 It means the dynamic presence and call of God to the Prophets (Jer 1:2-14). Athanasius presents a similar teaching to his work Letter to the people of Antioch, 26, 804AB: "But since also certain seemed to be contending together concerning the fleshly Economy of the Saviour, we enquired of both parties. And what the one confessed, the others also agreed to, that the Word did not, as it came to the prophets, so dwell in a holy man at the consummation of the ages, but that the Word Himself was made flesh, and being in the Form of God, took the form of a servant, and from Mary after the flesh became man for us, and that thus in Him the human race is perfectly and wholly delivered from sin and quickened from the dead, and given access to the kingdom of the heavens". 
The Incarnation includes the entire man and this is stated in the argument of G. Athanasius clearly. So there was no need for further reference to this teaching of Apollinaris. This recruitment of the entire man, soul and body is made to save man as a whole, not unilaterally. Christ was not an illusionary person but a real person. It was not a conversion of the Word of God, nor did he coexist consubstantially from the beginning of creation with God Logos. The meaning of the words "flesh" and "body" means the whole human being, it is perceived in the biblical perception and not in the ancient Greek meaning, which is why it emphasizes the biblical origin of these. The role of Virgin Mary is to give the flesh to God Logos. United with it, He coexists without the two natures becoming one. We have what later is called circumincession of each other or contradiction of the nature of Christ, the divine, and the human nature.

Finally, Crucifixion and Resurrection are events in which both natures are involved. The human nature suffers and the divine nature remains non sufferer. The same also applies to the natural and innocent passions. Christ as a human being, grows, is hungry, is thirsty, eats, and sleeps, functions which belong by nature to every man. The existence of the body of Christ does not require any change in the Holy Trinity. But the human body cannot be united with the Holy Trinity. The created element with the uncreated and spiritual one cannot compose a new entity, i.e. the Holy Tetras, for then we will have an equation of the creator and the creature.

\section{REFERENCES}

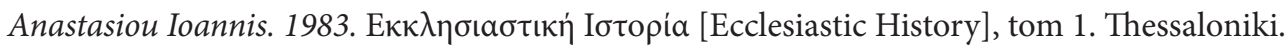

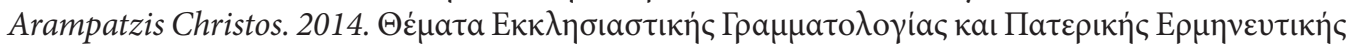

[Themes of Patrology and Interpretation of the Fathers of the Church]. Thessaloniki.

Athanasius Archbishop of Alexandria. Ad Epictetum Episcopum Corinthi contra haereticos Epistola, Migne Patrologia Graeca 26, 1049-1069.

Athanasius Archbishop of Alexandria. Tomus ad Antiochenos, Migne Patrologia Graeca 26, 796-810.

Bardy Gustave. 1938. Acace de Bérèe et son rôle dans la controverse nestorienne. In Revue des Sciences Religieuses 18, 20-44.

Casey Robert. 1933. An Armenian version of the Athanasius letter to Epictetus. In The Harvard Theological Review 26, 127-150.

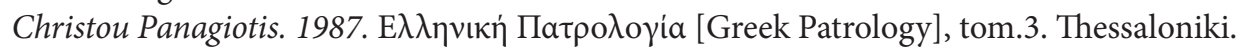

Cross Frank Leslie. 1945. The study of Athanasius. Oxford.

Cyril of Alexandria. Epistola XL ad Acacium Melitinem Episcopum, Migne Patrologia Graeca 77, 184-201.

Cyril of Alexandria. Epistola XXXIX ad Johannem Antiochensis Episcopum, Migne Patrologia Graeca 77, 173-181.

De Tillemont Nain Louis Sébastian 1702. Mémoires pour server de l'histoire ecclésiastique des six premières siècles, t. 8. Paris.

Epiphanius of Cyprus. Panarion, Migne Patrologia Graeca 42, 9-888.

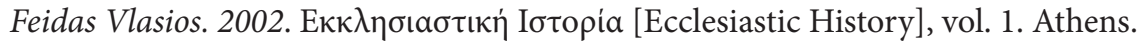

Gwynn David. 2012. Athanasius of Alexandria: bishop, Theologian, Ascetic, Father. Oxford.

Halleux de André. 1992. Les douzes chapitres cyrilliens au Concile d' Éphèse (430-433). In Revue théologique de Louvain 23, 425-458.

John of Antioch. Epistola XXXVIII ad Cyrillum, Migne Patrologia Graeca 77, 169-173.

Lebon Joseph. 1935. Altération doctrinal de la lettre à Epictète du saint Athanase. In Revue d'histoire ecclésiastique 31, 713-761. 
Ludwing Georg. 1911. Epistula ad Epictetum, Iena.

Martin Annick 1996. Athanase d’Alexandrie et l'Église d' Égypte au Ive s. (328 - 373), École Française de Rome. Rome.

Masai François. 1979. Moutsoulas E., La lettre d' Athanase d' Alexandrie à Epictète in Bulletin codicologique 33, 66.

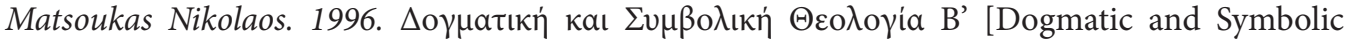
Theology B']. Thessaloniki.

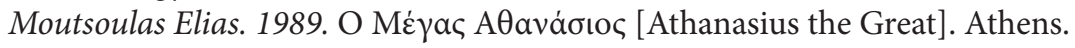

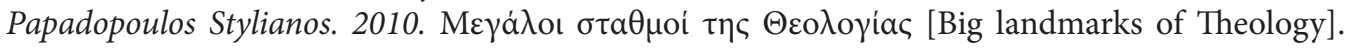
Athens.

Robertson Archibald. 1891. Select writings and letters of Athanasius bishop of Alexandria. Durham. Roldanus Johannes. 1977. Le Christ et l'homme dans la théologie d'Athanase d 'Alexandria. Leiden.

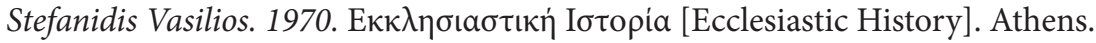

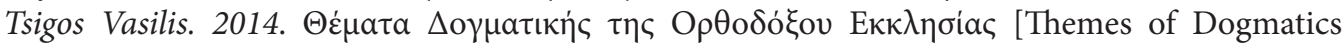
of the Orthodox Church]. Thessaloniki.

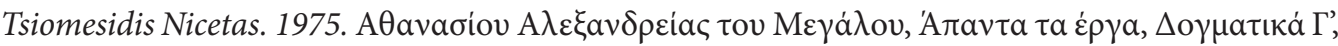
Eı $\sigma \alpha \omega \gamma \eta \dot{~[A t h a n a s i u s ~ o f ~ A l e x a n d r i a ~ t h e ~ G r e a t, ~ C o m p l e t e ~ w o r k s, ~ D o g m a t i c s ~ C ', ~ I n t r o d u c t i o n] . ~}$ In Greek Fathers of the Church 4, 9-14.

Zozulak, Jan. 2018. Interaction of Philosophy and Natural Sciences in Byzantine Empire. In Communications: Scientific Letters of the University of Zilina 20/1A, 8-15.

SUMMARY: TRINITY DOCTRINE AND CHRISTOLOGY OF SAINT ATHANASIUS, ARCHBISHOP OF ALEXANDRIA, IN HIS LETTER TO EPICTETUS, BISHOP OF CORINTH. The letter to Epictetus is a dogmatic letter in which St. Athanasius summarizes the teaching of the Church, as formulated till then, about the nature and the person of Christ, but also what he himself had thoroughly and extensively presented in his previous doctrinal texts. The content of this letter will be the bedrock of the faith that will be used in later theological controversies about the Virgin Mary and about two natures of Christ. Athanasius of Alexandria, both through the content of this letter and in his overall writings, is established not as an occasional writer of theological issues, but as a specialist doctrinaire of the Incarnation of the Word of God.

He does not present an extensive and specific treatise on the question, but he rather concentrates on a series of questions, which come from the views of Appolinarianists, Doketaí ("Illusionists") and adherents of early Nestorianism. But they end up in everything that M. Athanasius seeks every time through his teaching, that is to say, to emphasize the Incarnation of the Word of God and his and His consubstantiality with God the Father, timelessly, indivisibly and inexpressibly.

Apollinaris and his followers are not named in this letter, and it did not contain the revised heretical views concerning the basic appolinarianistic position on whether the Word took the place of the human soul into Christ. This is not because it is considered as a cover for Apollinaris or a latent apollinarianistic tendency by St. Athanasius, but because it is more interesting here for the Alexandrian hierarch to show that the salvation of man is connected with the Incarnation of the Word of God.

The Incarnation includes the entire man and this is stated in the argument of G. Athanasius clearly. So there was no need for further reference to this teaching of Apollinaris. This acceptance of the entire man, the soul and the body is made to save man as a whole, not unilaterally. Christ was not an illusionary person but a real person. It was not a conversion of the Word of God, nor did he co-exist consubstantially from the beginning of creation with God Logos. The meaning of the words "flesh" and "body" means the whole human being as it 
is perceived in the biblical perspective and not in the ancient Greek meaning, which is why it emphasizes the biblical origin of these.

The role of the Virgin Mary is to give the flesh to God Logos. United with it, He coexists without the two natures becoming one. We have what later is called circumincession of each other or contradiction of the nature of Christ, the divine, and the human nature.

Finally, Crucifixion and Resurrection are events in which both natures are involved. The human nature suffers and the divine nature remains non-sufferer. The same also applies to the natural and innocent passions. Christ as a human being, grows, is hungry, is thirsty, eats, and sleeps, functions which belong by nature to every man. The existence of the body of Christ does not require any change in the Holy Trinity. But the human body cannot be united with the Holy Trinity. The created element with the uncreated and spiritual one cannot compose a new entity, i.e. the Holy Tetras, for then we will have an equation of the creator and the creature.

Associate Professor Kyriakos S. Stavrianos, Ph.D.

University of Crete

Department of Preschool Education

University Campus - Gallos

74100 Rethymno

Greece

stavrianos@edc.uoc.gr 